\title{
Investasi Online Reksadana: Aspek Hukum dan Perlindungan Bagi Investor selaku Konsumen
}

\author{
Asriati Asriati ${ }^{1}$, Sumiati Sumiati ${ }^{2}$ \\ 1 Fakultas Hukum, Universitas Muslim Indonesia \\ 2 Fakultas Hukum, Universitas Ichsan Gorontalo \\ Email Correspondensi: asriati.asriati@umi.ac.id \\ No. Handphone Correspondensi : (+62) 821-8750-4001
}

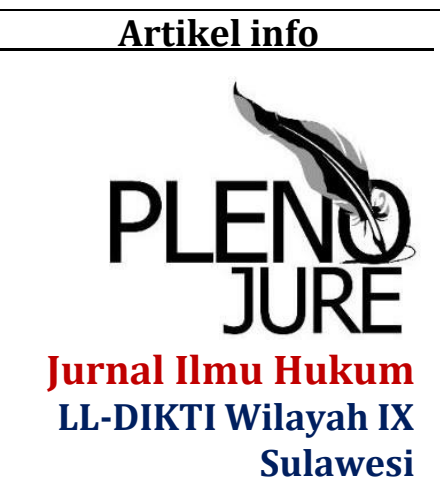

\begin{abstract}
Abstrak. Penelitian ini bermaksud untuk memahami dan menjelaskan pangaturan hukum terkait investasi online reksadana di Indonesia serta aspek perlindungan hukumnya terhadap investor selaku konsumen. Studi ini menggunakan metode penelitian hukum normative dengan mengkaji data sekunder dalam bentuk bahan hukum primer dan sekunder yang didukung oleh data wawancara. Hasil penelitian menunjukkan bahwa dalam konteks Indonesia, investasi online reksadana tidak diatur secara spesifik dalam aturan yang khusus, namun tersebar dalam sejumlah peraturan perundang-undangan. Demikian pula dengan aspek perlindungan hukum terhadap investor selaku konsumen reksadana online, antara lain: 1. Berdasarkan Undang-Undang Pasar Modal, awalnya invesatsi reksadana diawasi dan dilindungi oleh Bapepam-LK, yang kemudian dibubarkan dan dialihkan fungsinya ke Otoritas Jasa Keuangan (OJK). 2. Berdasarkan Undang-Undang tentang Otoritas Jasa Keuangan dan aturan turunannya, bentuk perlindungan hukum terhadap konsumen dilakukan secara preventif dan represif oleh OJK. 3. Berdasarkan Undang-Undang Perlindungan Konsumen, bentuk perlindungan dilakukan melalui Badan Perlindungan Konsumen Nasional (BPKN) yang kemudian membentuk Badan Penyelesaian Sengketa Konsumen (BPSK) di tingkat daerah.
\end{abstract}

Abstract. This study intends to understand and explain the
regulation related to online mutual fund investment in Indonesia
as well as aspects of legal protection for investors as consumers.
This study uses a normative legal research method by examining
secondary data in the form of primary and secondary legal
materials supported by interview data. The results show that in
the Indonesian context, online mutual fund investment is not
regulated in single and specific rules, but is spread out in several
laws and regulations. Likewise, the aspect of legal protection for
investors as online mutual fund consumers, which including: 1.
Based on the Capital Market Law, initially mutual fund
investments were supervised and protected by Bapepam-LK,
which was later dissolved and transferred to the Financial
Services Authority (OJK). 2 . Based on the Law concerning the
Financial Services Authority and its derivative regulations, the
form of legal protection for consumers is carried out in a
preventive and repressive manner by the OJK. 3 . Based on the
Consumer Protection Law, this form of protection is carried out


through the National Consumer Protection Agency (BPKN) which then forms a Consumer Dispute Resolution Agency (BPSK) at the regional level

\section{Keywords: \\ Legal protection; \\ Online Investment; \\ Mutual Funds;}

\section{PENDAHULUAN}

Dalam konteks negara berkembang maupun negara industri, penggunaan teknologi senantiasa menjadi kunci untuk menghasilkan kegiatan dan produk ekonomi yang inovatif. ${ }^{1}$ Terlebih, saat ini Indonesia tengah menghadapi revolusi industri 4.0, dimana semua proses dilakukan dengan sistem digitalisasi dan otomatisasi, hal mana yang memaksa sektor usaha untuk memutar otak dan terus berinovasi untuk bisa bertahan. ${ }^{2}$ Berdasarkan analisis Mckinsey Global Institute, Industri 4.0 menghasilkan dampak yang sangat massif dan signifikan pada aspek social dan ekonomi manusia, terutama pada sektor lapangan kerja dan mulai mensubtitusi peranan manusia. ${ }^{3}$ Perkembangan teknologi internet semakin berkembang dan tidak hanya menghubungkan manusia ke seluruh dunia namun juga menjadi suatu basis digitalisasi keuangan terutama di sektor investasi.4

Investasi secara umum memainkan peranan penting di sektor perekonomian, khususnya pada negara berkembang seperti Indonesia. Tanpa adanya investasi yang memadai maka sulit mengharapkan adanya pertumbuhan ekonomi yang tinggi dan berdampak pada kesejahteraan ekonomi bagi negara berkembang. ${ }^{5}$ Sejalan dengan perkembangan teknologi informasi dan internet, investasi online mulai menjadi primadona di masyarakat. Investasi online sendiri merupakan kegiatan penanaman modal secara digital dengan memanfaatkan teknologi internet. ${ }^{6}$ Model investasi ini juga semakin digemari oleh investor dikarenakan adanya fasilitas online trading yang ditawarkan oleh perusahaan sekuritas atau broker. Fasilitas online trading ini memudahkan para investor untuk dapat bertransaksi dimana pun dan kapan pun menggunakan perangkat (device) yang dapat mengakses internet sehingga memudahkan investor dalam pengambilan keputusan. ${ }^{7}$

Salah satu instrumen investasi yang menjadi pilihan investor adalah Reksadana. Dengan dukungan sistem online, investasi reksadana kini sangat mudah dan praktis untuk dilakukan. Masyarakat (investor) tidak perlu lagi

\footnotetext{
${ }^{1}$ Gamser, M. S. (1988). Innovation, technical assistance, and development: The importance of technology users. World Development, 16(6), 711-721.

2 Stăncioiu, A. (2017). The Fourth Industrial Revolution „Industry 4.0”. Fiabilitate Şi Durabilitate, 1(19), 7478.

3 Satya, V. E. (2018). Strategi Indonesia Menghadapi Industri 4.0. Info Singkat, 10(9), 19-24.

${ }^{4}$ Hamdan, H. (2018). Industri 4.0: Pengaruh Revolusi Industri Pada Kewirausahaan Demi Kemandirian Ekonomi.

${ }^{5}$ Inda Rahadiyan, 2014, Hukum Pasar Modal DI Indonesia (Pengawsan Pasar Modal Pasca Terbentuknya Otoritas Jasa Keuangan), UII Press Yogyakarta, Yogyakarta, h.17

6 Priharto, S. (2019) Mengenal Dan Membahas Lebih Jauh Tentang Investasi Online, dikutip dari https://cpssoft.com/blog/investasi/mengenal-investasi-online/ diakses pada 27 Desember 2020.

${ }^{7}$ Yusuf, M. (2019). Pengaruh Kemajuan Teknologi dan Pengetahuan terhadap Minat Generasi Milenial dalam Berinvestasi di Pasar Modal. Jurnal Dinamika Manajemen Dan Bisnis. hlm.2.
} 
datang ke bank kustodian atau menemui manager investasi untuk membeli reksadana. Sekarang investor dapat langsung bertransaksi melalui situs resmi (website) atau melalui aplikasi secara online. Contoh aplikasi investasi yang menjual reksadana secara online adalah Bibit dan Bareksa, adapun marketplace seperti Tokopedia dan Bukalapak. ${ }^{8}$

Namun demikian, di balik kemajuan teknologi investasi, masih terdapat sejumlah persoalan yang melintang. Salah satunya adalah minimnya literasi masyarakat mengenai investasi online. Salah satu studi mensurvei 530 investor online untuk memeriksa pemhaman mereka terkait literasi investasi, namun hanya $50 \%$ pertanyaan yang mampu dijawab dengan benar. ${ }^{9}$ Dalam konteks Indonesia, Berdasarkan Survei Nasional Literasi dan Inklusi Keuangan 2016, tingkat pemahaman masyarakat terhadap pasar modal dinilai masih kurang. Indeks literasi keuangan tahun 2016 pasar modal sebesar 4,4\% komposit, 4,4\% konvensional, dan 0,02\% syariah. Data tersebut menandakan masih rendahnya pengetahuan masyarakat terhadap investasi, termasuk mengenai reksadana.

Di samping itu, dibalik sejumlah kelebihannya, teknologi informasi juga mengandung celah hukum (flaws) yang berpotensi untuk disalahgunakan. Riset yang dilakukan oleh Eflyn Christie di tahun 2018, menguraikan bahwa Pemanfaatan teknologi investasi online pada faktanya menghasilkan modus baru dalam tindak pidana penipuan. ${ }^{10} \mathrm{Hal}$ ini umum terjadi dimana pelaku menggunakan serangkaian kebohongan mengenai suatu objek tertentu yang tidak sesuai dengan objek aslinya. Dimana rangkaikan kebohongan dan disinformasi tersebut digunakan untuk meraup manfaat serta keuntungan. Hingga saat ini Otoritas Jasa Keuangan (OJK) mencatat setidaknya ada 400 perusahaan investasi illegal alias investasi bodong di Indonesia. Salah satu contoh kasus adalah kasus investasi Dream For Freedom atau yang biasa disebut D4F yang dilakukan pada tahun 2016, D4F melakukan investasi yang dinilai tidak sesuai dengan aturan dalam proses legalitasnya. Terdakwa dalam kasus ini yakni pemilik bisnis D4F, Fili Muttaqien yang telah gagal dalam mengembalikan dana 700.000 orang investor dengan jumlah Rp. 3,5 Triliun. ${ }^{11}$ Kasus lainnya melibatkan PT EMCO Asset Management pada bulan Februari 2020 silam. Dimana sekitar 300 korban gagal bayar yang memiliki total kerugian mencapai Rp. 2,5 Triliun. Jumlah korban secara keseluruhan sejatinya jauh lebih banyak hingga menyentuh sekitar 2000 investor dengan nilai kerugian yang jauh lebih besar. ${ }^{12}$

Dengan banyaknya contoh kasus yang membuat masyarakat (investor) mengalami kerugian dalam investasi khususnya Reksadana online, perlindungan hukum diperlukan untuk melindungi serta memberikan kepastian dan jaminan hukum terhadap investor saat berinvestasi. Berdasarkan hal tersebut artikel ini bermaksud menguraikan perihal pengaturan hukum terkait investasi online Reksadana di Indonesia dan seperti apa bentuk perlindungan hukum terhadap konsumen dalam investasi online

\footnotetext{
${ }^{8}$ Fahlevi, R. (2018). Perlindungan Hukum Terhadap Investor Dalam Reksa Dana Syariah Berbentuk Perseroan.

${ }^{9}$ Volpe, R. P., Kotel, J. E., \& Chen, H. (2002). A survey of investment literacy among online investors. Journal of

Financial Counseling and Planning, 13(1), 1.

${ }^{10}$ Christy,E.(2018).Pertanggung Jawaban Pidana Pelaku Penipuan Melalui Investasi Online.

${ }^{11}$ Ibid.

${ }^{12 h}$ https://nasional.kontan.co.id/news/gagal-bayar-nasabah-resmi-laporkan-emco-asset-management-kebareskrim-polri
} 
Reksadana.

\section{METODE}

Artikel ini menggunakan metode penelitian hukum normatif, dengan jenis dan bahan hukum sekunder yang berasal dari bahan hukum primer. Bahan hukum yang sifatnya mengikat berupa peraturan perundang-undangan yang berlaku dan memiliki relevansi dengan kajian. Selain itu bahan hukum sekunder yang terdiri dari peraturan perundang-undangan, penelitian terdahulu, dan literatur jurnal hukum terkait. Sebagai pelengkap artikel ini penulis menggunakan dua teknik pengumpulan data yakni studi kepustakaan dan wawancara kepada narasumber yang terkait. Setelah mempelajari seluruh bahan hukum yang digunakan dalam artikel ini, penulis mengolah dan menganalisis secara deskriptif-kualitatif. Hasil dan pembahasan artikel ini menjadi jawaban bagi permasalahan yang dicetuskan.

\section{HASIL DAN PEMBAHASAN}

\section{A. Pengaturan Hukum Terkait Investasi Online Reksadana Di Indonesia}

Pada dasarnya, reksa dana merupakan salah satu alternatif investasi bagi konsumen pemodal, khususnya pemodal kecil dan pemodal yang tidak memiliki banyak waktu dan keahlian untuk menghitung risiko atas investasi mereka. ${ }^{13}$ Dengan demikian, Reksa Dana sendiri dirancang sebagai sarana untuk menghimpun dana dari masyarakat yang memiliki modal, mempunyai

keinginan untuk melakukan investasi, namun tidak memiliki waktu serta pengetahuan yang terbatas. ${ }^{14}$

Terkait pengaturannya secara umum, investasi Reksa dana rupanya masih diatur dalam beberapa jenis regulasi yang berbeda. Mengacu kepada Pasal 1 angka 27 UU No. 8 Tahun 1995 tentang Pasar Modal (UUPM), Reksa Dana adalah wadah yang dipergunakan untuk menghimpun dana dari masyarakat pemodal untuk selanjutnya diinvestasikan dalam Portofolio Efek oleh Manajer Investasi. ${ }^{15}$ Portofolio efek merupakan kumpulan efek yang dimiliki oleh orang perseorangan atau badan usaha dan kelompok, dalam bentuk surat berharga (Pasal 1 UU PM), sedangkan manajer investasi adalah mereka yang mengelola portofolio efek atau investasi kolektif dari para nasabah (Pasal 1 angka 11 UU PM).

Dilihat dari segi bentuknya, Reksa dana memiliki dua bentuk yaitu reksa dana Perseroan dan Kontrak Investasi Kolektif. ${ }^{16}$ Pasal 18 ayat (1) UndangUndang Pasar Modal menerangkan bahwa Reksa Dana berbentuk Perseroan adalah emiten yang kegiatan usahanya menjual saham dan selanjutnya dana dari penjualan saham itu diinvestasikan pada berbagai jenis efek yang diperdagangkan di pasar modal dan pasar uang. Reksa Dana berbentuk Perseroan pada dasarnya merupakan suatu perusahaan (perseroan terbatas), yang dari sisi bentuk hukum tidak berbeda dengan perusahaan lainnya, kecuali

\footnotetext{
13 Sujatmiko, A. (1998). Alternatif Investasi Melalui Reksa Dana. Perspektif, 3(2), 1-8.

${ }_{14}$ Asriwahyuni, I., \& Prima, G. A. (2017). Pengaruh Ukuran dan Umur Pada Kinerja Reksa Dana Saham di Indonesia. E-Jurnal Akuntansi Universitas Udayana, 21(2), 1460-1487.

${ }^{15}$ Masruroh, A. (2014). Konsep dasar investasi reksa dana. SALAM: Jurnal Sosial dan Budaya Syar-i, 1(1).

${ }^{16}$ Asril, J. (2018). Aspek Hukum Reksa Dana Berbentuk Kontrak Investasi Kolektif Dalam Hukum Positif Di Indonesia. Jurnal Ilmiah Mea (Manajemen, Ekonomi, \& Akuntansi), 2(3), 233-253.
} 
pada jenis usaha. ${ }^{17}$ Namun demikian, karena jenis usahanya yang berbentuk PT maka pengaturannya juga mesti mengacu pada UU No. 40 Tahun 2007 tentang Perseroan Terbatas. Dana yang disetorkan oleh investor kepada reksa dana perseroan terbagi dalam saham-saham. Oleh karena berbentuk PT, maka karakteristik utama reksa dana perseroan adalah badan hukum, sehingga tanggung jawab ada pada PT itu sendiri melalui Direksi.

Pada bentuk yang kedua, Reksa Dana dilakukan melalui Kontrak Investasi Kolektif (KIK) berdasarkan kesepakatan antara Manajer Investasi dan Bank Kustodian. Pasal 18 ayat 1b UU PM memberi penjelasan tentang pengertian Kontrak Investasi Kolektif (KIK) sebagai kontrak antara Manajer Investasi dan Bank Kustodian yang mengikat pemegang Unit Penyertaan dimana Manajer Investasi diberi wewenang untuk mengelola portofolio investasi kolektif dan Bank Kustodian diberi wewenang untuk melaksanakan penitipan kolektif. Tidak seperti reksa dana perseroan yang mengacu pada UU PM dan UU PT, pengaturan lebih lanjut terkait reksadana KIK masih merujuk pada Peraturan BAPEPAM No. IV.B.2 tentang Pedoman Reksa Dana Kontrak Investasi Kolektif. Misalnya ketentuan terkait identitas para pihak dan tanggung jawab manajer investasi dan Bank kustodian.

Khusus mengenai Reksa dana secara online, pengertiannya tetap merujuk ke UU PM sebagai undang-undang payung/pokok, namun demikian dengan karakteristiknya sebagai online investment, maka tetap merujuk pada konsep perjanjian online.$^{18}$ Perjanjian yang dilakukan secara online sering disebut sebagai perjanjian elektronik atau kontrak elektronik, yakni kontrak yang dibuat, disepakati, para pihak melalui jaringan internet. ${ }^{19}$ Perjanjian atau kontrak elektronik ini diatur dalam Undang- Undang Nomor 11 Tahun 2008 Tentang Informasi dan Transaksi Elektronik sebagaimana telah diubah dengan Undang- Undang Nomor 19 Tahun 2016 Tentang Perubahan Atas Undang-Undang Nomor 11 Tahun 2008 Tentang Informasi dan Transaksi Elektronik (UU ITE). Pasal 18 UU ITE menyatakan "Transaksi Elektronik yang dituangkan ke dalam Kontrak Elektronik mengikat para pihak". ${ }^{20}$

Perihal pengaturan reksa dana secara online pada umumnya sama terhadap reksa dana konvensional yang diatur dalam UUPM dari Pasal 18 hingga Pasal 29, hal-hal dasar yang diatur berupa ${ }^{21}$ : a. Bentuk Hukumnya; b. Persyaratan dan perizinan; c. Pemegang saham; d. Kewajiban manajer investasi; e. Pengelolaan; dan e. Kekayaan reksa dana. Namun demikian, reksa dana secara online memiliki peraturan tambahan yang mengaturnya yaitu: Pertama, Peraturan Otoritas Jasa Keuangan Nomor 39/POJK.04/2014 Tentang

\footnotetext{
${ }^{17}$ Dja'akum, C. S. (2014). Reksa Dana Syariah. Az Zarqa': Jurnal Hukum Bisnis Islam, 6(1).

18 Wisudawan, I. G. A., Zuhairi, A., \& Mulada, A. D. (2020). Formulasi Penegakan Hukum Terhadap Reksa Dana Yang Melakukan Perbuatan Melawan Hukum Menurut Hukum Positif Di Indonesia. Ganec Swara, 14(2), 699707.

${ }^{19}$ Pradnyamitha, D. P., \& Darmadi, A. A. S. W. (2016). Keabsahan Transaksi Online Di Tinjau Dari Hukum Perikatan. Kertha Semaya: Journal Ilmu Hukum, 6(9), 1-5.

${ }^{20}$ Fahlevi, R. (2018). Perlindungan Hukum Terhadap Investor Dalam Reksa Dana Syariah Berbentuk Perseroan.

21 Tanjung, N. E. (2020). Penggunaan Prinsip Kehati-Hatian Oleh Perusahaan Asuransi Dalam Menginvestasikan Aset Reksa Dana (Doctoral dissertation, UMSU).
} 
Agen Penjual Efek Reksa Dana (selanjutnya disebut POJK APERD). ${ }^{22}$ Kedua, Surat Edaran Otoritas Jasa Keuangan Nomor 7/SEOJK.04/2014 tentang Penerapan Pelaksanaan Pertemuan Langsung (Face to Face) Dalam Penerimaan Pemegang Efek Reksa Dana Melalui Pembukaan Rekening Secara Elektronik, Serta Tata Cara Penjualan (Subcription) Dan Pembelian Kembali (Redemption) Efek Reksa Dana Secara Elektronik (selanjutnya disebut dengan SEOJK PPPLRD). ${ }^{23}$

Pengaturan yang dasar mengenai reksa dana secara online terdapat dalam UUPM, sedangkan peraturan tambahan yang dikeluarkan OJK adalah aturan untuk kegiatan investasi reksa dana yang dilakukan secara online. Secara khusus UU OJK sendiri belum memuat aturan Investasi online reksadana secara terpadu dan sistematis dalam satu peraturan. ${ }^{24}$

Tabel 1. Pengaturan Investasi Online Reksadana

\begin{tabular}{|c|c|c|}
\hline No. & Jenis Peraturan & Substansi \\
\hline 1. & $\begin{array}{c}\text { Undang-Undang Nomor } 8 \\
\text { Tahun } 1995 \text { Tentang Pasar } \\
\text { Modal }\end{array}$ & $\begin{array}{c}\text { Pengertian Reksadana } \\
\text { Unsur-unsur reksadana } \\
\text { Bentuk Reksadana }\end{array}$ \\
\hline 2. & $\begin{array}{c}\text { Peraturan Otoritas Jasa } \\
\text { Keuangan Nomor } \\
\text { 39/P0JK.04/2014 }\end{array}$ & $\begin{array}{l}\text { Tentang Agen Penjual } \\
\text { Efek Reksa Dana } \\
\text { (APERD) }\end{array}$ \\
\hline 3. & $\begin{array}{c}\text { Surat Edaran Otoritas Jasa } \\
\text { Keuangan Nomor } \\
\text { 7/SEOJK.04/2014 }\end{array}$ & $\begin{array}{l}\text { Tentang Transaksi } \\
\text { Reksa Dana Secara } \\
\text { Elektronik }\end{array}$ \\
\hline 4. & Peraturan Bapepam-LK & $\begin{array}{c}\text { Pedoman Pengelolaan } \\
\text { Reksa Dana Berbentuk } \\
\text { Perseroan \& Berbentuk } \\
\text { Kontrak Investasi } \\
\text { Kolektif (KIK) }\end{array}$ \\
\hline 5. & $\begin{array}{c}\text { Undang-Undang Nomor } 19 \\
\text { Tahun } 2016 \text { Tentang } \\
\text { Informasi dan Transaksi } \\
\text { Elektronik }\end{array}$ & $\begin{array}{c}\text { Perjanjian atau Kontrak } \\
\text { Elektronik }\end{array}$ \\
\hline
\end{tabular}

${ }^{22}$ Sejumlah hal yang diatur mencakup: a. Persyaratan APERD b. Perizinan, Pendaftaran, dan Pemberitahuan c. Kontrak penjualan efek d. Pejabat penanggung jawab e. Kantor lain selain gerai penjualan f. Perilaku APERD g. Pelaporan

${ }^{23}$ Secara garis besar mengatur tentang Penerapan tentang pelaksanaan langsung dalam hal penerimaan pemegang efek reksa dana melalui pembukaan rekening yang secara elektronik; dan Tata cara terkait penjualan (subscription) dan pembelian kembali (redemption) efek reksa dana yang secara elektronik.

${ }^{24}$ Nikmah Mentari, S. H. (2019). Pemberian ganti rugi investor di pasar modal melalui disgorgement fund (Doctoral dissertation, UNIVERSITAS AIRLANGGA). 


\section{B. Bentuk Perlindungan Hukum Terhadap Konsumen Dalam Investasi Online Reksadana Di Indonesia}

Menurut Satjipto Rahardjo, perlindungan hukum dapat dimaknai sebagai upaya memberikan pengayoman terhadap Hak Asasi Manusia (HAM) yang dirugikan orang lain dan diberikan kepada masyarakat agar dapat menikmati semua hak-hak yang diberikan oleh hukum. ${ }^{25}$ Dalam konteks investasi, perlindungan hukum sangat diperlukan untuk melindungi investor dari resiko yang harus ditanggung oleh investor itu sendiri dalam melasanakan kegiatan investasi. ${ }^{26}$ Terlebih beberapa tahun terakhir kegiatan investasi online khususnya reksa dana begitu marak, sehingga dibutuhkan suatu perangkat hukum agar investasi tersebut teratur, dan adil bagi semua pihak.

Menurut R. La Porta dalam Jurnal of Financial Economics, bentuk perlindungan hukum yang diberikan oleh suatu memiliki dua sifat, yaitu bersifat pencegahan (prohibited) dan bersifat hukuman (sanction)..27 Mengingat sejumlah pengaturan mengenai investasi online reksa dana tersebar di beberapa peraturan perundang-undangan, maka aspek perlindungan hukumnya akan diuraikan sebagai berikut:

\section{Perlindungan hukum terhadap Konsumen Investasi Online Reksadana Menurut Undang-Undang Nomor 8 Tahun 1995 Tentang Pasar Modal}

Pengawasan di bidang pasar modal pada awalnya berada di bawah pengawasan Badan Pengawasan Pasar Modal \& Lembaga keuangan (BapepamLK) berdasarkan Undang-Undang Nomor 8 Tahun 1995 tentang Pasar Modal bahwa pembinaan, pengaturan, dan pengawasan sehari-hari Pasar Modal dilakukan oleh Bapepam-LK.28 Namun Pada akhir 2011, sebagai upaya reformasi sektor keuangan, Pemerintah dan Dewan Perwakilan Rakyat (DPR) sepakat mendirikan Otoritas Jasa Keuangan (OJK). Kemudian, pada tanggal 22 November 2012, Undang-Undang No 21 tentang Otoritas Jasa Keuangan disahkan. Lembaga yang disebut independen ini berfungsi mulai 31 Desember 2012 dimana menggantikan fungsi, tugas dan wewenang pengaturan yang selama ini dilakukan oleh Kementerian Keuangan melalui Badan Pengawas Pasar Modal serta Lembaga Keuangan (Bapepam-LK). ${ }^{29}$

Berdasarkan hasil wawancara kepada Chandra Assidiq selaku salah satu Tim Pengawasan Pasar Modal Kantor OJK Regional 6 Sulampua ${ }^{30}$ bahwa Bapepam-LK kini sudah melebur menjadi OJK beserta fungsi dan kewenangan yang sesuai dengan UU No 21 Tahun 2011, sehingga Bapepam-LK sudah tidak lagi eksis baik secara badan maupun secara fungsi. Dulunya Bapepam-LK

\footnotetext{
${ }^{25}$ Rahardjo, S. (2000). Ilmu Hukum (Cetakan ke-V). Bandung: PT Citra Aditya Bakti.

${ }^{26}$ Rachmadini, V. N. (2020). Perlindungan Hukum Bagi Investor Dalam Pasar Modal Menurut Undang-Undang Pasar Modal Dan Undang-Undang Otoritas Jasa Keuangan. Pena Justisia: Media Komunikasi dan Kajian Hukum, 18(2).

${ }^{27}$ La Porta, R., Lopez-de-Silanes, F., Shleifer, A., \& Vishny, R. (2000). Investor protection and corporate governance. Journal of financial economics, 58(1-2), 3-27. h.9.

${ }^{28}$ Mawei, S. (2016). Pengawasan Pasar Modal Di Indonesia Pasca Terbentuknya Otoritas Jasa Keuangan. Lex Privatum, 4(6).

${ }^{29} \mathrm{Ibid}$.

${ }^{30}$ Wawancara dengan Chandra Assidiq Tim Pengawasan Pasar Modal OJK Regional 6 Sulawesi, Maluku, Papua. Pada tanggal 5 Maret 2021
} 
melakukan kegiatan perizinan, pengaturan, pengawasan, dan terhadap sektor Pasar Modal dan Lembaga Keuangan NonBank dan saat ini fungsi beserta tugas Bapepam-LK telah beralih ke OJK sebagai regulator industri jasa keuangan yang mengatur dan mengawasi sektor Perbankan, Pasar Modal, dan Industri Jasa Keuangan Non-Bank

\section{Perlindungan Konsumen Investasi Online Reksadana Menurut Undang- Undang Nomor 21 Tahun 2011 Tentang Otoritas Jasa Keuangan}

Berdasarkan Pasal 6 Undang-Undang Nomor 21 Tahun 2011 Tentang Otoritas Jasa Keuangan (UU OJK), OJK melaksanakan tugas pengaturan dan pengawasan terhadap kegiatan jasa keuangan di sektor Perbankan, kegiatan jasa keuangan di sektor Pasar Modal, dan kegiatan jasa keuangan di sektor Perasuransian, Dana Pensiun, Lembaga Pembiayaan, dan Lembaga Jasa Keuangan Lainnya. ${ }^{31}$ Saat dikonfirmasi mengenai apa fungsi dan tugas dari OJK terkhusus di bidang Pasar Modal, Chandra Assidiq pun menambahkan bahwa dalam bidang Pasar Modal Otoritas Jasa Keuangan (OJK) mempunyai fungsi menyelenggarakan sistem pengaturan dan pengawasan yang terintegrasi antara sektor Pasar Modal terhadap keseluruhan kegiatan di sektor jasa keuangan lain serta memiliki tugas melakukan pengaturan dan pengawasan terhadap kegiatan jasa keuangan di sektor Pasar Modal, Perbankan, serta sektor IKNB. ${ }^{32}$ Dalam hal ini, investasi reksa dana online juga termasuk pada kegiatan jasa keuangan di sektor pasar modal. Maka aspek perlindungan konsumen dalam investasi online reksa dana yang disebut sebagai perlindungan terhadap investor, merupakan salah satu yang menjadi kewenangan dari OJK.

Bentuk perlindungan hukum yang dilakukan OJK terhadap konsumen (investor) bersifat pencegahan atau preventif dan pemberian sanksi atau represif, mengingat bahwa tugas $0 \mathrm{JK}$ adalah menjalankan fungsi pengaturan dan pengawasan sektor jasa keuangan. ${ }^{33}$

Berdasarkan Pasal 28 UU OJK memberikan perlindungan hukum yang bersifat mencegah kerugian konsumen dan masyarakat (preventif) dalam bentuk: ${ }^{34}$

a) memberikan informasi dan edukasi kepada masyarakat atas karakteristik sektor jasa keuangan, layanan, dan produknya;

b) meminta Lembaga Jasa Keuangan untuk menghentikan kegiatannya apabila kegiatan tersebut berpotensi merugikan masyarakat; dan

c) tindakan lain yang dianggap perlu sesuai dengan ketentuan peraturan perundang-undangan di sektor jasa keuangan.

Khusus Pasal 29 UU OJK menyatakan, bahwa OJK melakukan pelayanan pengaduan konsumen yang meliputi: ${ }^{35}$

\footnotetext{
${ }^{31}$ Santi, E., Budiharto, B., \& Saptono, H. (2017). Pengawasan Otoritas Jasa Keuangan Terhadap Financial Technology (Peraturan Otoritas Jasa Keuangan Nomor 77/POJK. 01/2016). Diponegoro law journal, 6(3), 1 20.

32 Wawancara dengan Chandra Assidiq Tim Pengawasan Pasar Modal OJK Regional 6 Sulawesi, Maluku, Papua. Pada tanggal 5 Maret 2021

33 Dimyati, H. H. (2014). Perlindungan hukum bagi investor dalam pasar modal. Jurnal Cita Hukum, 2(2).

${ }^{34}$ Rachmadini, V. N. Op.cit

${ }^{35}$ Samsul, I. (2016). Perlindungan Konsumen Jasa Keuangan Pasca Pembentukan Otoritas Jasa Keuangan (OJK). Negara Hukum: Membangun Hukum Untuk Keadilan Dan Kesejahteraan, 4(2), 153-166.
} 
a) Menyiapkan perangkat yang memadai untuk pelayanan pengaduan Konsumen yang dirugikan oleh pelaku di Lembaga Jasa Keuangan;

b) Membuat mekanisme pengaduan Konsumen yang dirugikan oleh pelaku di Lembaga Jasa Keuangan;

c) Memfasilitasi penyelesaian pengaduan Konsumen yang dirugikan oleh pelaku di Lembaga Jasa Keuangan sesuai dengan peraturan perundangundangan di sektor jasa keuangan.

OJK selaku lembaga pengawasan dan pengaturan terhadap keseluruhan kegiatan di sektor jasa keuangan, khususnya reksa dana memberikan perlindungan secara preventif dengan mengeluarkan peraturan yang berkaitan dengan reksa dana secara online yakni Peraturan Otoritas Jasa Keuangan Nomor 39/POJK.04/2014 Tentang Agen Penjual Efek Reksa Dana (selanjutnya disebut POJK APERD) aturan ini dikeluarkan OJK untuk menjamin kepastian hukum dan dalam rangka perkembangan industri reksa dana. ${ }^{36}$

Bentuk perlindungan hukum lainnya yang bersifat represif adalah jika terjadi sengketa antara konsumen dengan perusahaan industri jasa keuangan, maka OJK berwenang melakukan pembelaan hukum demi kepentingan konsumen (investor) dan masyarakat. ${ }^{37}$ Pembelaan hukum tersebut meliputi memerintahkan perusahaan jasa keuangan untuk menyelesaikan pengaduan yang dilakukan oleh konsumen yang merasa dirugikan melalui cara : ${ }^{38}$

a) Memerintahkan atau melakukan tindakan tertentu kepada Lembaga Jasa Keuangan untuk menyelesaikan pengaduan konsumen yang dirugikan Lembaga Jasa Keuangan dimaksud;

b) Mengajukan gugatan untuk memperoleh kembali harta kekayaan milik pihak yang dirugikan dari pihak yang menyebabkan kerugian, baik yang berada di bawah penguasaan pihak yang menyebabkan kerugian dimaksud maupun di bawah penguasaan pihak lain dengan itikad tidak baik; dan/atau untuk memperoleh ganti kerugian dari pihak yang menyebabkan kerugian pada konsumen dan/atau Lembaga Jasa Keuangan sebagai akibat dari pelanggaran atas peraturan perundang-undangan di sektor jasa keuangan.

Perlindungan represif yang diberikan OJK adalah dengan menerapkan sanksi hukum terhadap pelanggaran keterbukaan informasi, penipuan, manupulasi pasar dan perdagangan orang dalam berupa sanksi administratif, perdata, serta pidana. ${ }^{39}$ Pada Pasal 102 UUPM memberikan kewenangan kepada OJK untuk menerapkan sanksi administratif atas pelanggaran dari ketentuan UUPM. Sanksi tersebut berupa peringatan tertulis, pembatasan dan pembekuan kegiatan usaha, pencabutan izin usaha, pembatalan persetujuan dan pendaftaran. Selain sanksi tersebut OJK dapat melaksanakan tindakan

\footnotetext{
${ }^{36}$ Yolanda, M. (2019). Pelaksanaan Regulatory Sandbox Oleh Otoritas Jasa Keuangan Dalam Rangka Meningkatkan Perlindungan Konsumen (Doctoral dissertation, Universitas Islam Indonesia).

${ }^{37}$ Iyustina, S. A. Kedudukan Otoritas Jasa Keuangan (Ojk) dalam Perlindungan Hukum Bagi Masyarakat Bedasarkan Pasal 28 Undang-undang Nomor 21 Tahun 2011 Tentang Otoritas Jasa Keuangan (Studi Kasus Investasi Save Our Trade di Kabupaten Mempawah). Jurnal Nestor Magister Hukum, 3(3), 210374.

${ }^{38}$ Fadilla, R. H., \& Budiharto, P. P. (2016). TANGGUNG JAWAB DIREKSI PERUSAHAAN SEKURITAS YANG MELAKUKAN TRANSAKSI REPURCHASE AGREEMENT (REPO) OBLIGASI FIKTIF. Diponegoro Law Journal, $5(3), 1-12$

${ }^{39}$ Septiana, H. K. (2021). Analisis Tanggung Jawab Hukum Terhadap Tindak Pidana Manipulasi Pasar Dan Perlindungan Hukum Bagi Investor Minoritas Studi Kasus: Posa. JISIP (Jurnal Ilmu Sosial dan Pendidikan), 5(2).
} 
terhadap pihak-pihak yang melanggar ketentuan OJK. Selanjutnya pada Pasal 104 dan 107 UUPM menerapkan sanksi pidana terhadap pihak-pihak yang melakukan perbuatan menyesatkan dalam bentuk penipuan, manipulasi pasar, dan perdagangan orang dalam. Pada Pasal 111 UUPM juga menerapkan sanksi perdata berupa pertanggung jawaban ganti rugi. ${ }^{40}$

Chandra Assidiq menjelaskan, Bentuk perlindungan hukum terhadap konsumen OJK juga lakukan secara represif, apabila ada sebuah tindakan menyimpang yang dilakukan oleh pelaku jasa keuangan terkait dan terbukti menyimpang maka pihak tersebut akan dikenakan sanksi sesuai aturan yang berlaku. Salah satu contoh sanksi yakni seperti menutup dan mencabut izin perusahaan tersebut melalui koordinasi antar lembaga. Serta apabila perusahaan investasi bodong itu tidak mempunyai izin dari OJK maka yang mempunyai wewenang yakni SWI (Satgas Waspada Investigasi) untuk melaporkan ke pihak kepolisian untuk ditindak lanjuti. ${ }^{41}$

\section{Perlindungan Konsumen Investasi Online Reksadana Menurut Undang- Undang Nomor 8 Tahun 1999 Tentang Perlindungan Konsumen}

Dalam dunia investasi online khususnya reksa dana, investor dapat dikategorikan juga sebagai konsumen yang dimana sangat perlu mendapat perlindungan dari negara. Berdasarkan Pasal 1 Undang-Undang No. 8 Tahun 1999 tentang Perlindungan Konsumen yang dinyatakan abhwa "Perlindungan Konsumen adalah segala upaya yang menjamin adanya kepastian hukum untuk memberi perlindungan kepada konsumen." 42

Dalam rangka mengembangkan upaya perlindungan konsumen maka dibentuklah Badan Perlindungan Konsumen Nasional (BPKN) dan bertanggung jawab kepada Presiden. ${ }^{43}$ Pembentukan BPKN berdasarkan pada ketentuan Undang-Undang No. 8 Tahun 1999 tentang Perlindungan Konsumen (UUPK) yang ditindaklanjuti dengan PP No. 5 Tahun 2001 dan diganti PP No. 4 Tahun 2019 Tentang Badan Perlindungan Konsumen Nasional. ${ }^{44}$ Badan Perlindungan Konsumen Nasional mempunyai fungsi memberikan saran dan pertimbangan kepada pemerintah dalam upaya mengembangkan perlindungan konsumen di Indonesia. Untuk melaksanakan fungsi tersebut Badan Perlindungan Konsumen Nasional mempunyai tugas: ${ }^{45}$

a. Memberikan saran dan rekomendasi kepada pemerintah dalam rangka penyusunan kebijaksanaan di bidang perlindungan konsumen.

b. Melakukan penelitian dan pengkajian terhadap peraturan perundangundangan yang berlaku di bidang perlindungan konsumen.

\footnotetext{
${ }^{40}$ Mayasonda, R., Abubakar, L., \& Rahmawati, E. (2020). Kajian Terhadap Rencana Pengaturan Disgorgement Dalam Pasar Modal Indonesia. JCH (Jurnal Cendekia Hukum), 6(1), 1-12.

${ }^{41}$ Wawancara dengan Chandra Assidiq Tim Pengawasan Pasar Modal OJK Regional 6 Sulawesi, Maluku, Papua. Pada tanggal 5 Maret 2021

${ }^{42}$ Setyawati, D. A., Ali, D., \& Rasyid, M. N. (2017). Perlindungan Bagi Hak Konsumen dan Tanggung Jawab Pelaku Usaha Dalam Perjanjian Transaksi Elektronik. Syiah Kuala Law Journal, 1(3), 46-64.

${ }^{43}$ Permana, I. K. B. T., \& Dewi, A. I. A. A. (2016). Tugas-tugas Badan Perlindungan Konsumen Nasional. Kertha Semaya: Journal Ilmu Hukum, 5(1).

${ }^{44}$ Retor, A. M. C. (2019). HAK KONSUMEN TERHADAP STANDAR MUTU BAKU BARANG DITINJAU DARI UU NO. 8 TAHUN 1999 TENTANG PERLINDUNGAN KONSUMEN. LEX PRIVATUM, 7(7).

${ }^{45}$ Pantouw, M. P. (2016). Peran dan Fungsi Lembaga Pengawasan dalam Tanggung Jawab Pelaku USAha Menurut UU No. 8 Tahun 1999 Tentang Perlindungan Konsumen. Lex Crimen, 5(6).
} 
c. Melakukan penelitian terhadap barang dan/atau jasa yang menyangkut keselamatan konsumen.

d. Mendorong berkembangnya lembaga perlindungan konsumen swadaya masyarakat.

e. Menyebarluaskan informasi melalui media mengenai perlindungan konsumen dan memasyarakatkan sikap keberpihakan kepada konsumen.

f. Menerima pengaduan tentang perlindungan konsumen dari masyarakat, lembaga perlindungan swadaya masyarakat, atau pelaku usaha.

g. Melakukan survei yang menyangkut kebutuhan konsumen.

Berdasarkan dengan Pasal 2 ayat 3 PP Nomor 4 Tahun 2019 Tentang Badan Perlindungan Konsumen Nasional menjelaskan bahwa "Dalam hal diperlukan, untuk meningkatkan kinerja, BPKN dapat membentuk perwakilan di ibukota daerah provinsi", oleh sebab itu BKPN membentuk Badan Penyelesaian Sengketa Konsumen (BPPSK) untuk menjadi perwakilan diberbagai daerah. BPSK sendiri merupakan lembaga non struktural yang berkedudukan di Kabupaten dan Kota yang mempunyai fungsi menyelesaikan sengketa konsumen di luar pengadilan. ${ }^{46}$ Pembentukan BPSK ini berdasarkan pada adanya kecenderungan masyarakat yang segan untuk beracara di pengadilan karena posisi konsumen yang secara sosial dan finansial tidak seimbang dengan pelaku usaha. Kehadiran BPSK diresmikan pada tahun 2001, yaitu dengan adanya Keputusan Presiden Nomor 90 Tahun 2001 tentang Pembentukan Badan Penyelesaian Sengketa Konsumen. ${ }^{47}$

Dalam Pasal 1 angka 11 UU Perlindungan Konsumen dinyatakan bahwa Badan Penyelesaian Sengketa Konsumen (BPSK) adalah badan yang bertugas menangani dan menyelesaikan sengketa antara pelaku usaha dan konsumen. Dalam perlindungan dan penyelesaian persoalan konsumen, BPKN dan BPSK mempunyai peran yang serupa namun bedanya BPKN tidak menyelesaikan sengketa konsumen, kewenangan tersebut berada di BPSK. ${ }^{48}$ Penyelesaian sengketa di BPSK adalah melalui persidangan tanpa bantuan pengacara. Setiap sengketa yang masuk pada lembaga ini akan diutamakan untuk diselesaikan melalui jalur musyawarah secara kekeluargaan. ${ }^{49}$ Kelebihan tersendiri yang dimiliki BPSK adalah tidak membutuhkan waktu yang lama dalam prosedur maupun putusan yang dikeluarkan serta murah karna biaya persidangan yang dibebankan sangat ringan dapat terjangkau oleh konsumen. ${ }^{50}$

Persidangan pada Badan Penyelesaian Konsumen dapat ditempuh melalui 3 (tiga) cara, yaitu $:^{51}$

\footnotetext{
${ }^{46}$ Rahman, A. (2018). Penyelesaian Sengketa Konsumen Melalui Badan Penyelesaian Sengketa Konsumen (BPSK) Kota Serang. Jurnal Ilmu Hukum, 2(1).

${ }^{47}$ Ibid.

${ }^{48}$ Tamba, I. (2018). Peran Bpsk dalam Penyelesaian Sengketa Konsumen di Indonesia untuk sebagai Wujud Cita-cita Perlindungan Konsumen di Bidang Ekonomi. Ensiklopedia of Journal, 1(1), 79-84.

${ }^{49}$ Saragih, R. R. (2019). Faktor-Faktor di Batalkannya Putusan Badan Penyelesaian Sengketa Konsumen Oleh Pengadilan Negeri (Studi Putusan Nomor: 281/Pdt. Sus BPSK/2017/PN. Mdn) (Doctoral dissertation, Universitas Medan Area).

${ }^{50}$ Mahardika, I., \& Syaputra, M. (2020). Peran Badan Penyelesaian Sengketa Konsumen (Bpsk) Dalam Menyelesaikan Sengketa Konsumen Di Luar Pengadilan (Studi Pada Bpsk Kota Mataram) (Doctoral dissertation, Universitas_Muhammadiyah_Mataram).

${ }^{51}$ Rahman, A. (2018). Op.cit.
} 
a. Persidangan dengan cara Arbitrase

Arbitrase merupakan cara penyelesaian sengketa perdata yang dilakukan di luar peradilan umum dan didasarkan pada perjanjian arbritase yang dibuat oleh para pihak yang bersengketa.

b. Persidangan dengan cara Konsiliasi

Penyelesaian sengketa dengan konsiliasi memiliki banyak kesamaan dengan arbitrase dimana menyerahkan sengketa kepada pihak kita untuk diberikan pendapatnya kemudian disampaikan kepada para pihak. Namun pendapat konsiliator tidak mengikat sebagaimana mengikatnya putusan arbitrase.

c. Persidangan dengan cara Mediasi

Mediasi adalah proses penyelesaian sengketa dengan perantara pihak ketiga, yakni pihak yang memberi masukan-masukan kepada para pihak untuk menyelesaikan sengketa mereka.

Adapun keputusan yang diambil oleh majelis BPSK bersifat final dan mengikat, sesuai dengan metode penyelesaian yang dipilih oleh konsumen, apakah mediasi, konsiliasi, atau arbitrase. Artinya, setiap pihak yang terlibat dalam persidangan atau kasus sengketa yang diajukan berhak untuk melaksanakan putusan tanpa terkecuali ((Pasal 54 ayat (3) Undang-Undang Nomor 8 Tahun 1999 tentang Perlindungan Konsumen jo. Pasal 42 ayat (1)), Keputusan Menteri Perindustrian dan Perdagangan RI Nomor 100 350/Mpp/Kep/12/2001 tentang Pelaksanaan Tugas dan Wewenang Badan Penyelesaian Konsumen). Namun sesuai dengan Pasal 56 Ayat (2) UUPK disebutkan bahwa para pihak dapat mengajukan keberatan kepada Pengadilan Negeri paling lambat 14 (empat belas) hari kerja setelah menerima pemberitahuan putusan BPSK.

Pada dasarnya, untuk menghindari dari penipuan investasi online maka investor harus memahami mengenai kejelasan dan kebenaran atas informasi dari pihak penghimpun dana sebelum mereka menginvestasikan dana nya. Investor pun harus mengecek pihak penghimpun dana yang dipilih harus mempunyai izin dari OJK. Apabila terjadi pelanggaran atau penipuan terhadap konsumen (investor) dalam konteks reksa dana, maka konsumen (investor) dapat melaporkan serta menggugat ke BPSK setempat dengan mengikuti prosedur yang telah dijelaskan sebelumnya

\section{SIMPULAN DAN SARAN}

Berdasarkan uraian di atas, dapat disimpulkan bahwa Investasi Reksa Dana secara online di Indonesia belum diatur secara spesifik dan terpadu dalam peraturan tersendiri, melainkan masih merujuk pada sejumlah peraturan perundang-undangan, antara lain Undang-Undang Nomor 8 Tahun 1995 Tentang Pasar Modal (UUPM), Undang-Undang Nomor 19 Tahun 2016 Tentang Informasi dan Transaksi Elektronik, POJK Nomor 39/POJK.04/2014, SEOJK Nomor 7/SEOJK.04/2014, dan Peraturan Bapepam-LK yang masih dijadikan rujukan oleh 0JK. Terkait perlindungan hukum terhadap konsumen reksa dana online yang dalam hal ini adalah investor, dapat merujuk pada beberapa peraturan perundang-undangan yakni Undang-Undang Nomor 8 Tahun 1995 Tentang Pasar Modal (UUPM), Undang-Undang Nomor 21 Tahun 2011 Tentang Otoritas Jasa Keuangan dalam bentuk perlindungan hukum preventif dan 
represif yang dilakukan OJK. Sedangkan, menurut Undang-Undang Nomor 8 Tahun 1999 Tentang Perlindungan Konsumen, maka perlindungan dilakukan melalui Badan Perlindungan Konsumen Nasional (BPKN) dan Badan Penyelesaian Sengketa Konsumen (BPSK) di tingkat daerah yang dapat melakukan penyelesaian secara arbitrase, konsiliasi, dan mediasi, sebelum konsumen menempuh jalur litigasi.

Terkait pengaturan investasi reksa dana secara online, kedepannya pemerintah perlu mengatur investasi reksa dana online secara lex specialis dalam satu undang-undang khusus yang mengatur perihal investasi berbasis elektronik, termasuk reksa dana ataupun perdagangan surat berharga lainnya dalam bentuk online. Sedangkan terkait dengan perlindungan hukum, perlu ada koordinasi dan Kerjasama antara OJK dan BPKN/BPSK dalam menjamin perlindungan bagi konsumen (investor) reksa dana terutama berbasis elektronik (online). Mengingat saat ini, OJK belum mempunyai data yang komprehensif mengenai investasi online yang potensi terjadinya fraud cukup besar.

\section{UNGKAPAN TERIMAKASIH}

Ucapan terimakasih kepada sponsor, atau yang terlibat dalam membantu pendanaan, memperlancar kegiatan penelitian, diuraikan dalam bentuk paragraf singkat. [Cambria, 11, normal].

\section{DAFTAR RUJUKAN}

Asril, J. (2018). Aspek Hukum Reksadana Berbentuk Kontrak Investasi Kolektif Dalam Hukum Positif Di Indonesia. Jurnal Ilmiah MEA (Manajemen, Ekonomi, \& Akuntansi), 2(3), 233-253.

Asriwahyuni, I., \& Prima, G. A. (2017). Pengaruh Ukuran dan Umur Pada Kinerja Reksa Dana Saham di Indonesia. E-Jurnal Akuntansi Universitas Udayana, 21(2), 1460-1487.

Christy, E. (2018). Pertanggung Jawaban Pidana Pelaku Penipuan Melalui Investasi Online. Jurist-Diction.

Desak Putu Pradnyamitha. (2018). Keabsahan Transaksi Online Ditinjau Dari Hukum Perikatan, Kertha Semaya: Vol.06, No.9.

Dimyati, H. H. (2014). Perlindungan hukum bagi investor dalam pasar modal. Jurnal Cita Hukum, 2(2).

Dja'akum, C. S. (2014). Reksa Dana Syariah. Az Zarqa': Jurnal Hukum Bisnis Islam, 6(1).

Fadilla, R. H., \& Budiharto, P. P. (2016). Tanggung Jawab Direksi Perusahaan Sekuritas Yang Melakukan Transaksi Repurchase Agreement (REPO) Obligasi Fiktif. Diponegoro Law Journal, 5(3), 1-12.

Fahlevi, R. (2018). Perlindungan Hukum Terhadap Investor Dalam Reksa Dana 
Syariah Berbentuk Perseroan.

Gamser, M. S. (1988). Innovation, technical assistance, and development: The importance of technology users. World Development, 16(6), 711-721.

Gunawan Widjaja dan Almira Prajna Ramaniya. (2006). Seri Pengetahuan Pasar Modal: Reksa Dana dan Peran Serta Tanggung Jawab Manajer Investasi Dalam Pasar Modal. Kencana: Prenada Media Group, Jakarta.

Hamdan, H. (2018). Industri 4.0: Pengaruh Revolusi Industri Pada Kewirausahaan Demi Kemandirian Ekonomi.

Inda Rahadiyan. (2014). Hukum Pasar Modal DI Indonesia (Pengawsan Pasar Modal Pasca Terbentuknya Otoritas Jasa Keuangan). UII Press Yogyakarta, Yogyakarta.

Iwan P. Pontjowinoto, Peran Manajer Investasi dalam Reksa Dana, BAPEPAM, Capital Market Society (CMS), Majalah Uang dan Efek. Jakarta.

Iyustina, S. A. Kedudukan Otoritas Jasa Keuangan (Ojk) dalam Perlindungan Hukum Bagi Masyarakat Bedasarkan Pasal 28 Undang-undang Nomor 21 Tahun 2011 Tentang Otoritas Jasa Keuangan (Studi Kasus Investasi Save Our Trade di Kabupaten Mempawah). Jurnal Nestor Magister Hukum, 3(3), 210374.

Mahardika, I., \& Syaputra, M. (2020). Peran Badan Penyelesaian Sengketa Konsumen (BPSK) Dalam Menyelesaikan Sengketa Konsumen DIluar Pengadilan (Studi Pada BPSK Kota Mataram). (DoctoraldissertationUniversitas_Muhammadiyah_Mataram).

Mawei, S. (2016). Pengawasan Pasar Modal Di Indonesia Pasca Terbentuknya Otoritas Jasa Keuangan. Lex Privatum, 4(6).

Mayasonda, R., Abubakar, L., \& Rahmawati, E. (2020). Kajian Terhadap Rencana Pengaturan Disgorment Dalam Pasar Modal Indonesia. JCH (Jurnal Cendekia Hukum), 6(1), 1-12.

Muklis, F. (2016). Perkembangan dan tantangan pasar modal Indonesia. AlMasraf: Jurnal Lembaga Keuangan dan Perbankan, 1(1), 65-76.

Nikmah Mentari, S. H. (2019). Pemberian ganti rugi investor di pasar modal melalui disgorgement fund (Doctoral dissertation, UNIVERSITAS AIRLANGGA).

Pantouw, M. P. (2016). Peran dan Fungsi Lembaga Pengawasan dalam Tanggung Jawab Pelaku Usaha Menurut UU No. 8 Tahun 1999 Tentang Perlindungan Konsumen. Lex Crimen, 5(6)

Permana, I. K. B. T., \& Dewi, A. I. A. A. (2016). Tugas-tugas Badan Perlindungan Konsumen Nasional. Kertha Semaya: Journal Ilmu Hukum, 5(1).

Rachmadini, V. N. (2020). Perlindungan Hukum Bagi Investor Dalam Pasar Modal Menurut Undang-Undang Pasar Modal Dan Undang-Undang 
Otoritas Jasa Keuangan. Pena Justisia: Media Komunikasi dan Kajian Hukum, 18(2).

Rahman, A. (2018). Penyelesaian Sengketa Konsumen Melalui Badan Penyelesaian Sengketa Konsumen (BPSK) Kota Serang. Jurnal Ilmu Hukum, 2(1).

Retor, A. M. C. (2019). Hak Konsumen Terhadap Standar Mutu Baku Barang Ditinjau Dari UU No. 8 Tahun 1999 Tentang Perlindungan Konsumen. Lex Privatum, 7(7).

Samsul, I. (2016). Perlindungan Konsumen Jasa Keuangan Pasca Pembentukan Otoritas Jasa Keuangan (OJK). Negara Hukum: Membangun Hukum Untuk Keadilan Dan Kesejahteraan, 4(2), 153-166.

Santi, E., Budiharto, B., \& Saptono, H. (2017). Pengawasan Otoritas Jasa Keuangan Terhadap Financial Technology (Peraturan Otoritas Jasa Keuangan Nomor 77/POJK. 01/2016). Diponegoro law journal, 6(3), 120.

Saragih, R. R. (2019). Faktor-Faktor di Batalkannya Putusan Badan Penyelesaian Sengketa Konsumen Oleh Pengadilan Negeri (Studi Putusan Nomor: 281/Pdt. Sus BPSK/2017/PN. Mdn) (Doctoral dissertation, Universitas Medan Area).

Sari, A. P. N., \& Purwanto, A. (2012). Analisis Kebijakan Alokasi Aset, Kinerja Manajer Investasi dan Tingkat Risiko terhadap Kinerja Reksa dana Saham di Indonesia (Doctoral dissertation, Fakultas Ekonomika dan Bisnis).

Satya, V. E. (2018). Strategi Indonesia MenghadapiIndustri 4.0. Info Singkat, 10(9), 19-24.

Septiana, H. K. (2021). Analisis Tanggung Jawab Hukum Terhadap Tindak Pidana Manipulasi Pasar Dan Perlindungan Hukum Bagi Investor Minoritas Studi Kasus: Posa. JISIP (Jurnal Ilmu Sosial dan Pendidikan), $5(2)$.

Stăncioiu, A. (2017). The Fourth Industrial Revolution „Industry 4.0”. Fiabilitate Şi Durabilitate, 1(19), 74-78.

Sujatmiko, A. (1998). Alternatif Investasi Melalui Reksa Dana. Perspektif, 3(2), $1-8$.

Tamba, I. (2018). Peran Bpsk dalam Penyelesaian Sengketa Konsumen di Indonesia untuk sebagai Wujud Cita-cita Perlindungan Konsumen di Bidang Ekonomi. Ensiklopedia of Journal, 1(1), 79-84.

Tampubolon, W. S. (2016). Upaya Perlindungan Hukum Bagi Konsumen Ditinjau Dari Undang Undang Perlindungan Konsumen. Jurnal Ilmiah Advokasi, 4(1), 53-61.

Tanjung, N. E. (2020). Penggunaan Prinsip Kehati-Hatian Oleh Perusahaan 
Asuransi Dalam Menginvestasikan Aset Reksa Dana (Doctoral dissertation, UMSU).

Taslim, G. W. (2019). Stagnasi Kinerja BPSK Semarang Pasca Penetapan UU No. 23 Tahun 2014 Tentang Pemerintah Daerah. Jurnal Riptek, 11(2), 7586.

Wisudawan, I. G. A., Zuhairi I, A., \& MULADA, A. D. (2020). Formulasi Penegakan Hukum Terhadap Reksa Dana Yang Melakukan Perbuatan Melawan Hukum Menurut Hukum Positif Di Indonesia. Ganec Swara, 14(2), 699707.

Yolanda, M. (2019). Pelaksanaan Regulatory Sandbox Oleh Otoritas Jasa Keuangan Dalam Rangka Meningkatkan Perlindungan Konsumen. (Doctoral dissertation, Universitas Islam Indonesia).

\section{Peraturan}

Undang-Undang Dasar Republik Indonesia Tahun 1945.

Undang-Undang Republik Indonesia Nomor 8 Tahun 1999 Tentang Perlindungan Konsumen.

Undang-Undang Republik Indonesia Nomor 40 Tahun 2007 Tentang Perseroan Terbatas

Undang-Undang Republik Indonesia Nomor 21 Tahun 2011 Tentang Otoritas Jasa Keuangan (OJK).

Undang-Undang Republik Indonesia Nomor 8 Tahun 1995 Tentang Pasar Modal.

Undang-Undang Republik Indonesia Nomor19 Tahun 2016 tentang Perubahan Atas Undang-Undang Nomor 11 Tahun 2008 Tentang Informasi Dan Transaksi Elektronik.

Peraturan Otoritas Jasa Keungan tentang Perlindungan Konsumen Sektor Jasa Keuangan.

Peraturan Badan Pengawas Pasar Modal dan Lembaga Keuangan 